ppi $201502 Z U 4645$

Esta publicación científica en formato digital es continuidad de la revista impresa ISSN-Versión Impresa 0798-1406 / ISSN-Versión on line 2542-3185Depósito legal pp $197402 Z$ U34
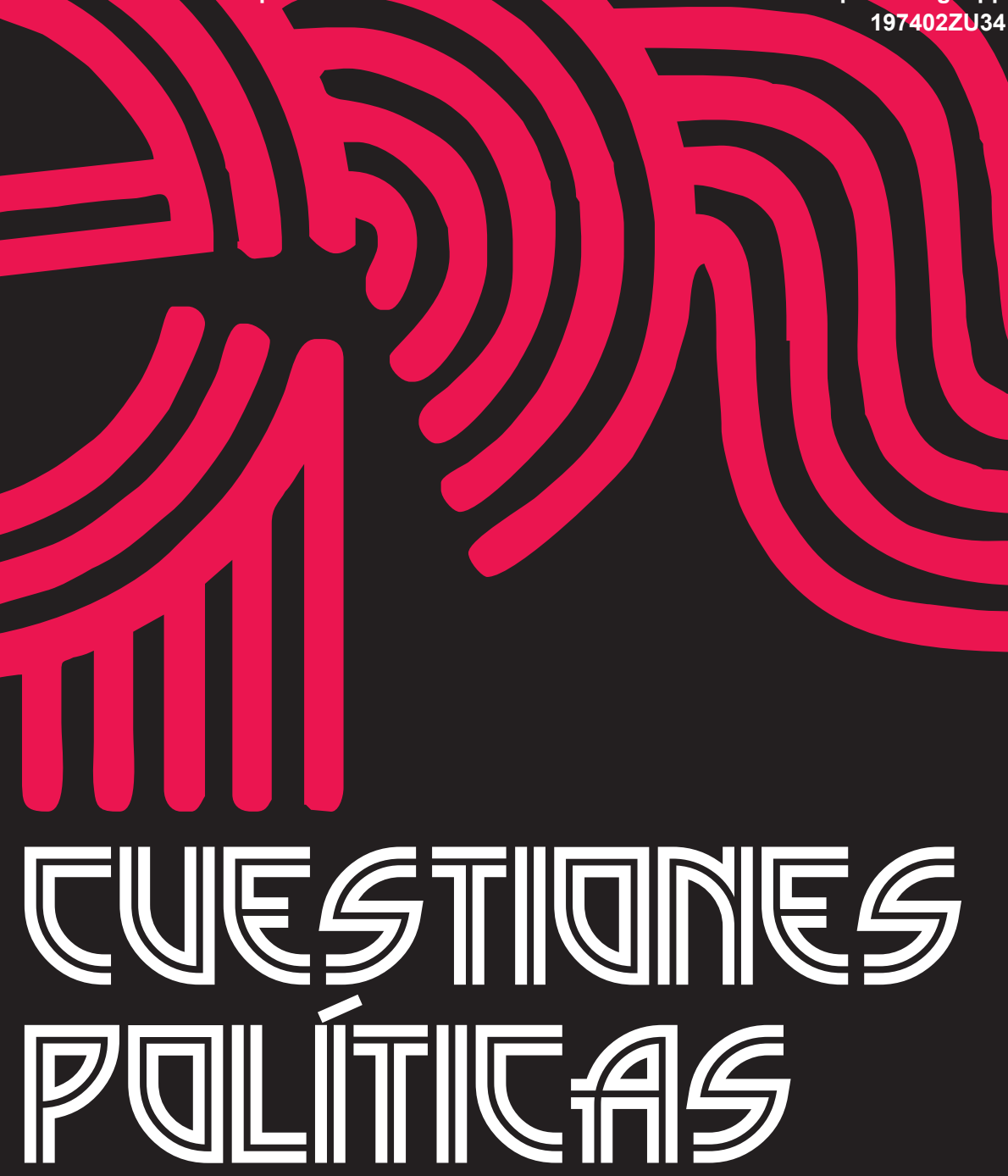

Instituto de Estudios Políticos y Derecho Público "Dr. Humberto J. La Roche" de la Facultad de Ciencias Jurídicas y Políticas de la Universidad del Zulia Maracaibo, Venezuela
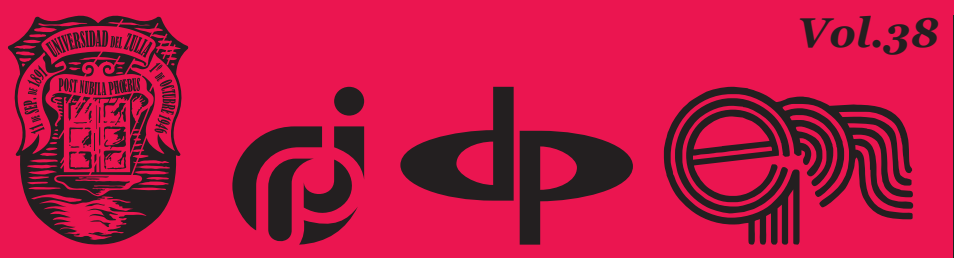

$N^{\circ}$ Especial 2da Parte 2020 


\title{
Religious Associations in Tatar Assr under Conditions of Mass Political Repressions of the 1930
}

\author{
DOI: https://doi.org/10.46398/cuestpol.382e.02
}

\begin{abstract}
Ruslan Rustamovich Ibragimov * Aivaz Minnegosmanovich Fazliev ** Chulpan Khamitovna Samatova ***
\end{abstract}

\begin{abstract}
The paper discusses the situation of confessional associations in the Autonomous Soviet Socialist Republic of Tatar during the period of mass political repressions de in the late 1930s. The methodological basis was the civilizational approach, as well as the principles of objectivity, historicism, and social focus, which allowed the most effective development of the issue raised. The specificity of the period and the object of study are determined by the heyday of Stalinist repression and religious consciousness, which was carried by believers and clergy, and was not correlate with communist ideology. The very fact of the existence of the aforementioned believers and the clergy and the presence of Orthodox churches, mosques, Catholic churches and functioning religious buildings of other religions was fundamentally in line with the goals and objectives that the state authorities established during this period. By way of conclusion, the authors provide detailed statistical information (in support of their scientific arguments and conclusions) on the dynamics of the number of prayer buildings in the republic during the study period and at the same time account of the general conditions of mass repression that characterize the historical context.
\end{abstract}

Keywords: soviet state; Russian Orthodox Church; Islam, mass political repression; atheism and materialism.

* Candidate of Historical Sciences, Associate Professor, Department of Russian History, Institute of International Relations; Kazan Federal University, Kremliovskaya St., 18, 4200o8, Kazan, Russian Federation. ORCID ID: https://orcid.org/oooo-0oo1-8879-1190. Email: rus-ibr@inbox.ru

** Candidate of Historical Sciences, Associate Professor, Department of Russian History, Institute of International Relations; Kazan Federal University, Kremliovskaya St., 18, 4200o8, Kazan, Russian Federation. ORCID ID: oooo-0oo3-4317-9533. Email: aivazik@mail.ru

*** Candidate of Historical Sciences, Associate Professor, Department of Historical and Social Studies, Institute of International Relations, Kazan Federal University, Kremliovskaya St., 18, 420008, Kazan, Russian Federation. ORCID ID: https://orcid.org/oooo-ooo1-5462-436X. Email: chulpansamatova@mail.ru 
Ruslan Rustamovich Ibragimov, Aivaz Minnegosmanovich Fazliev y Chulpan Khamitovna Samatova

\section{Asociaciones religiosas en Tatar Assr bajo condiciones de represiones políticas masivas en la década de 1930}

\section{Resumen}

El documento analiza la situación de las asociaciones confesionales en la República Socialista Soviética Autónoma de tártaro durante el período de represiones políticas masivas de fines de la década de 1930. La base metodológica fue el enfoque civilizacional, así como los principios de objetividad, historicismo y enfoque social, que permitieron desarrollar de la manera más eficaz el tema planteado. La especificidad del período y el objeto de estudio están determinados por el apogeo de la represión estalinista y la conciencia religiosa, que fue llevada por los creyentes y el clero, y no se correlacionó con la ideología comunista. El hecho mismo de la existencia de los creyentes mencionados y del clero y la presencia de iglesias ortodoxas, mezquitas, iglesias católicas y edificios religiosos en funcionamiento de otras religiones fue fundamentalmente discordante con las metas y objetivos que las autoridades estatales establecieron durante este período. A modo de conclusión los autores proporcionan información estadística detallada (en apoyo de sus argumentos y conclusiones científicos) sobre la dinámica del número de edificios de oración en la república durante el período de estudio y al mismo tiempo dan cuenta de las condiciones generales de represión masiva que caracteriza el contexto histórico.

Palabras clave: estado soviético; Iglesia ortodoxa rusa; islam, represión política masiva; ateísmo y materialismo.

\section{Introduction}

The scientific issues presented in the paper have long been in the focus of the scientific attention of historians. In the Soviet period of Russian historiography, it could be considered only from the point of view of criticism of religious consciousness. In this regard, the works published in this period have certain ideological dogmas and stereotypes. Nevertheless, it should be noted that significant factual material was collected and systematized in them (Baltanov, 1973; Evdokimov, 1967; Filimonov, 1983; Ishmukhametov, 1979; Krylov, 1960).

Changes in the socio-political life of the country during the years of perestroika and the ensuing collapse of the USSR led to fundamentally new approaches to the study of this problem. In addition, historians gained access to previously closed archival funds, and to the possibility of cooperation with foreign colleagues. As a result, many works were published in the post- 
Soviet period, when the problem under study received a fundamentally new and comprehensive analysis (Aralovets, 1995; Braslavsky, 1997; Braslavsky, 1995; Zemskov, 1995; Litvin, 1993; Mukhametshin, 2003; Nabiev, 2002; Odintsov, 1994; Pospelovsky, 1995; Yunusova, 1999; Yakunin, 2002; Nafikov and Nabiev, 2018; Fazliev et al., 2018).

A foreign historiography of the problem developed in a conceptually different format (Fletcher, 1973; Bennigsen and Wimbush, 1986; Devlet, 1991; Rorlich, 1986). Its specificity is largely determined by the sociocultural and sociopolitical conditions of work of researchers. At the beginning of the 2oth century, the Russian Empire was a multi-ethnic and multi-confessional state. Religion played a decisive role in many spheres of life of the peoples of Russia regardless of their confession and ethnicity, in fact shaping the worldview of the people.

The coming to power of the Bolsheviks in Russia was a turning point for the country. Since that time, there has been a revolutionary change not only in the socio-political and economic structure of the state; the spiritual foundations of Russian society have also undergone radical changes. The Bolsheviks, whose views were based on a materialistic worldview, viewed religion as their ideological adversary capable of influencing the consciousness of individuals. Therefore, atheism became one of the postulates dominating in the ideology of the new state power.

By 1917, in addition to the traditional confessions of this region: Islam and Orthodoxy, other beliefs were spread in the territory of the Kazan province. There were operated the following communities: Catholics, Lutherans, Jews, Old Believers of the Belokrinitsky and Priestless Hierarchies, various Protestant movements (evangelists, Baptists, Pentecostals, Adventists) (Nabiev, 1997). In accordance with the legislation of the Russian Empire, the above religions were endowed with various rights and obligations. With the adoption by the Bolsheviks in November 1917 of the "Declaration of the Rights of the Peoples of Russia", all existing national religious privileges and restrictions were abolished; all confessions were granted equal rights to fulfil their religious needs (Collection of normative acts on Soviet state law, 1984).

In the first decade of Soviet power, its attitude towards confessions was to a certain extent differentiated: Muslims, as well as followers of the Gospel and Baptist sects were in a somewhat more preferred position. The reason for this, in each case, was specific. In a Muslim society, Islam is not just a religion, but a way of life. Violent changes in the traditional way of life of Muslim peoples could lead to large-scale protests against the new government.

Therefore, at a certain stage, the policy of the Soviet state regarding Islam was relatively flexible. Its manifestations were: "An appeal to the 
Ruslan Rustamovich Ibragimov, Aivaz Minnegosmanovich Fazliev y Chulpan Khamitovna Samatova

working Muslims of Russia and the East”, which affirmed the inviolability of their beliefs, customs and national-cultural institutions (Legislation on religious cults, 1971); the return to Muslims of relics such as the Koran of Osman, the Syuyumbike tower in Kazan, the Caravanserai in Orenburg (Legislation on religious cults, 1971); permission to teach Muslim creeds in mosques (based on the decisions of the Presidium of the All-Russian Central Executive Committee dated July 9 and July 28, 1924 (they were cancelled in 1928 by a decision of the Presidium of the Central Executive Committee of the USSR) (Nabiev, 2002).

Reflection of this trend in the Tatar Autonomous Soviet Socialist Republic was the continuation of the construction of the Zakabannaya mosque in Kazan and the construction of mosques in the villages of the republic (Nadyrov, 2000). However, already in the late 1920s, the Soviet state's policy regarding Islam was reduced to the level of other confessions, which in general terms was expressed in the forced closure of prayer buildings, and in repressions against believers and the clergy.

As for Evangelicals and Baptists, the authorities used them as a tool to combat with the influence of the Russian Orthodox Church. In this regard, taking into account the presence of pacifist ideas in sectarian dogma, on January 4, 1919, the Decree "On Relief from Military Duties for Religious Beliefs" was adopted. Directly in Kazan, there was a practice when, in the 1920-1930s the authorities transferred Orthodox churches to the communities of evangelical Christians (Kornilov, 2003).

In order to divide the Russian Orthodox Church, in 1923 the authorities initiated the creation of a Renovated Church. In this regard, the Renovated Church Diocesan Administration also operated in Kazan until 1938 along with the Orthodox Kazan diocese.

\section{Methods}

The civilizational approach is chosen as the methodological basis of the study. It allows us to explore the problem of interest in a multidimensional format, considering it in the social, political, cultural, and economic segments. Ultimately, this allows us to provide the most complete picture of the functioning conditions of the religious associations in the Tatar Autonomous Soviet Socialist Republic during the study period.

When working on the paper, the authors were guided by the principles of historicism, objectivity and a social approach. The first of them obliges to investigate facts and events from the point of view of where, when, for whatever reason they arose and developed in accordance with the historical situation. The principle of objectivity obliges to dissociate ourselves from 
various subjective factors that can affect the purity and objectivity of the study. The principle of a social approach involves considering the events and processes that took place in the case within the framework of the studied problem and period, taking into account the interests of various layers of Soviet society.

\section{Results and Discussion}

The general political situation in the USSR at the end of the 1930s was characterized by the onset of "great terror", the aim of which was the final establishment of a totalitarian regime in the country. When this goal was achieved, all social layers of the Soviet state were subjected to repression, which, in turn, led to the creation of ideal conditions for total repression in relation to the society of believers and clergy who were initially alien to the official ideology.

During the anti-religious campaign at the turn of the 1930s and 40s, believers and clergy became acutely aware of their lack of rights. Stalin's thesis about the intensification of the class struggle under the conditions of advancing socialism, as applied to religious associations, was expressed not only in the intensification of atheist propaganda, but also in the intensification of the activities of the law enforcement agencies against them. A wave of repression swept across the country: it was directed against believers and especially the clergy.

The means of propaganda represented the believers only as “... opponents of socialism and the Soviet system" (Odintsov, 1995: 55), and worshipers were portrayed as "....an overt or covert counter-revolutionary force" (Odintsov, 1995: 39). A manifestation of the new onslaught on religion was the fact that in 1938 the publication of the newspaper "Nothingarian" suspended in 1934 was resumed. In such an environment of victimization and persecution, a significant part of the clergy was forced to abandon their activities, and those who did not do so were forced to be partly repressed. So, according to D.V. Pospelovsky, “...during the 30 s the number of priests in the original territory of the Soviet Union decreased by 95\%" (Pospelovsky, 1995: 511), and according to the Commission under the President of the Russian Federation for the Rehabilitation of Victims of Political Repressions, during the years of Soviet power, 500 thousand religious figures were subjected to repression, of which 200 thousand were executed (Krasikov, 2000).

The same insignificant part of the clergy who managed to avoid direct repression was taken into special account. Each minister of worship was obliged to go through a detailed questionnaire, which determined the 
Ruslan Rustamovich Ibragimov, Aivaz Minnegosmanovich Fazliev y Chulpan Khamitovna Samatova

degree of loyalty of this person to the existing regime. The activities of the remaining religious associations were under the supervision of employees and secret informants of the NKVD; in the event that they discovered any violations of the law on cults by the former, representatives of the clergy and believers were arrested.

It cannot be argued that the facts of gross administration, victimization, persecution, and repression were perceived by the faithful and the clergy completely without complaint. The only form of disagreement with the actions of local authorities was the preparation of complaints to higher authorities or to the governing institution called upon to monitor compliance with the law on cults. But, during the anti-religious campaign, an event was carried out aimed at depriving religious associations of legal support, which for more than twenty years was provided by the state itself, mainly formally. Moreover, "... in the middle of the year 37th, there was widespread circulation among the party and Soviet activists... of an opinion about the need to completely eliminate the legislation on cults" (Odintsov, 1990: 57). In line with such trends, in 1938 the Permanent Commission on Cults under the Presidium of the CEC of the USSR was abolished. From now on, until 1943, believers and the clergy actually lost the opportunity to appeal against the facts of a gross and undisguised violation of their rights.

As in other regions of the country, a wave of repressions against the clergy and believers also took place in the Tatar Autonomous Soviet Socialist Republic. Back in 1930, the case "on the counter-revolutionary religiousmonarchist organization as the branch of the counter-revolutionary centre of the "True Orthodox Church in the Tatar Autonomous Soviet Socialist Republic" was fabricated, during which former professors of the Kazan Theological Academy V.I. Nesmelov and N.V. Petrov, former Kazan vicar bishop I. Udalov, bishop N. Trezvinsky, priest N.M. Troitsky et al. were convicted (Litvin, 1993).

In contrast to the anti-religious campaign of 1918-1925, when the main blow was directed against the Russian Orthodox Church, in the late 1920 s - 1930s. repressive measures were held against each and every confession. In subsequent years, according to A.L. Litvin, “... dozens of mullahs were executed in Tatarstan" (Litvin, 1993: 222). The number of repressed worshipers of all confessions in the TASSR only for 1932-1933 amounted to 234 people (Ivanov, 2000).

The most difficult time for the religious associations of the Tatar Autonomous Soviet Socialist Republic was the period of 1939-1941. Its beginning coincided with the 18th Congress of the CPSU (B), where it was announced that the construction of a socialist society in the USSR was (mainly) completed and, of course, "a country of victorious socialism" could not have a place for such a "relic" of social consciousness as religion. In this regard, the party and Soviet leaders on the ground began to eradicate eagerly 
the remnants of the past. So, in the Kalininsky district (now the territory of the Aktanyshsky and Muslyumovsky districts of the Republic of Tatarstan), by 1941 out of 68 inactive prayer buildings, 52 were closed precisely during this period (National Archives of the Republic of Tatarstan).

In other regions of the republic, these figures were distributed as follows: in the Muslumovsky district - 48 and 29 (National Archives of the Republic of Tatarstan. Fund R-873. Inventory 2. Case 5); in the Yudinsky district - 25 and 18 (National Archives of the Republic of Tatarstan. Fund R-873. Inventory 2. Case 19); in Vysokogorsky district - 21 and 14 (National Archives of the Republic of Tatarstan. Fund R-873. Inventory 2. Case 16); in the Dubyaz district - 55 and 30 (National Archives of the Republic of Tatarstan. Fund R-873. Inventory 2. Case 16); in the Kaybitsky district 23 and 17 (National Archives of the Republic of Tatarstan. Fund R-873. Inventory 2. Case 9); in the Telmansky district (now the territory of the Aksubaevsky, Bilyarsky and Oktyabrsky districts) - 23 and 17 (National Archives of the Republic of Tatarstan. Fund R-873. Inventory 2. Case 28); in Rybno-Slobodsky - 36 and 22 (National Archives of the Republic of Tatarstan. Fund R-873. Inventory 2. Case 30); in the Tyulyachinsky district - 45 and 40 (National Archives of the Republic of Tatarstan. Fund R-873. Inventory 2. Case 30), etc.

During this period, the closure of churches, mosques and houses of worship was really churned out. A common occurrence in the activities of the Presidium of the Supreme Council of the TASSR was the adoption of more than a dozen such decisions during one meeting. With this approach, there could be no question of a comprehensive and thorough investigation of each individual case concerning a particular religious building. So, 23 prayer buildings were closed by only one decree of the Presidium of the Supreme Council of the TASSR dated May 5, 1939.

It should be noted that until the second half of the 1930s, the closure of prayer buildings was not documented legally in many cases, that is, "decisions of the general meeting of residents" or strong-willed decisions of representatives of local authorities, as a result of which prayer buildings ceased to function, were not recorded anywhere. In the future, this practice could create significant difficulties in substantiating the legitimacy of the presence of new "owners" in the cult buildings. Therefore, in the late 1930s, the closure of many prayer buildings from those that actually ceased to function in the 1920 s and early 1930 s was legally formalized.

For example, among the prayer buildings closed in 1939 there was the Peter and Paul Church in Kazan. The reason for this was that "...the community of believers at the Peter and Paul Church does not ensure the full preservation of the extremely valuable architectural features of the Peter and Paul Church..." (National Archives of the Republic of Tatarstan. Fund R-873. Inventory 2. Case 1). A similar formulation of the Presidium of 
the Kazan City Council entailed a Decree of the Presidium of the Supreme Council of the TASSR dated August 13, 1939, on "...closing the Peter and Paul Church in Kazan and transferring the church building to the TASSR People's Commissariat for use as an anti-religious museum and lecture hall" (National Archives of the Republic of Tatarstan. Fund R-873. Inventory 2. Case 1). Such actions by the authorities were widespread.

As a result of the frontal onslaught on religion, its associations lost their significance and status as quite independent and influential institutions of society, which they were until 1917. Moreover, by the beginning of World War II, the religious policy of the Soviet state (which was essentially antireligious) almost reached its purpose, a society was built in which atheism became the dominant form of consciousness of the vast majority of its individuals. According to official data of those years, the number of believers was decreasing every day and vice versa, the number of villages, towns, cities and regions in which there was not a single officially functioning prayer building and religious association was constantly increasing (Barmenkov, 1979).

In this respect, the Tatar Autonomous Soviet Socialist Republic was no exception. By 1941, only two communities of the Russian Orthodox Church officially functioned on its territory in the cities of Kazan and Menzelinsk. Figures also speak about the scope of the anti-religious campaign: in 1935-1941, about 1.5 thousand prayer buildings were closed in the Tatar Autonomous Soviet Socialist Republic (National Archives of the Republic of Tatarstan. Fund R-873. Inventory 2. Case 1).

Atheistic propaganda has also achieved considerable success in educating a generation of die-hard atheists. By 1931, the number of members of the Union of violent Atheists in the TASSR was 16872 people only among citizens of Tatar nationality (Kasymov, 1932).

\section{Conclusions}

In the first decade of Soviet power, the attitude of the state towards various confessions was uneven. During this period, Muslim and Protestant communities were in a relatively better position in the republic. In the first case, this was dictated by the fear of the authorities concerning the upsurge of nationalist protests in response to the oppression of Islam, which in Muslim society was not just a religion, but also a way of life. As for Evangelicals and Baptists, the authorities used them as a tool to combat the influence of the Russian Orthodox Church.

In the 1920-1930s, a wave of repression against the clergy took place in the republic. Moreover, if in the first half of the 1920 s they were mainly 
affected by representatives of the Russian Orthodox Church, then in the late 1920 - 1930 s the clergy of all faiths were repressed. The most difficult time for the religious associations of the republic was 1939-1941. During this period, mass closures of prayer buildings and repressions against clergy and believers were held.

By the beginning of World War II, religious associations in the Tatar Autonomous Soviet Socialist Republic were on the verge of complete destruction as a result of the massive ideological work of atheist propaganda, repressions against believers and the clergy, as well as after three all-Union anti-religious campaigns. Thus, religious life actually shifted to an illegal level; the vast majority of remaining believers and clergy were forced to meet their religious needs secretly from the authorities and a large part of atheistically inclined Soviet society.

\section{Acknowledgements}

The work is performed according to the Russian Government Program of Competitive Growth of Kazan Federal University.

\section{Bibliographic References}

ARALOVETS, Navena. 1995. "Losses of the population in the Soviet society in the 1930s: problems, sources, methods of study in Russian historiography" In: Domestic History. Vol. 1, 135-146.

BALTANOV, Ravil'Gubaidullovich. 1973. Sociological problems within the system of scientific and atheistic education (problems of a concrete sociological analysis of religion and atheism in the USSR). Kazan University Press. Kazan, Russia.

BARMENKOV, Aleksel Ivanovich. 1979. Freedom of conscience in the USSR. Chuvash book publishing house. Cheboksary, Russia.

BENNIGSEN, Alexandre; WIMBUSH, Enders. 1986. Muslims of the Soviet Empire: A Guide. Indiana University Press. Bloomington, United States.

BRASLAVSKY, Ido Yu. 1997. Islam in Chuvashia. Chuvashia. Cheboksary, Russia.

BRASLAVSKY, Ido Yu. 1995. Orthodox churches of Chuvashia. Chuvash book publishing house. Cheboksary, Russia. 
Ruslan Rustamovich Ibragimov, Aivaz Minnegosmanovich Fazliev y Chulpan Khamitovna Samatova

COLLECTION OF NORMATIVE ACTS ON SOVIET STATE LAW. 1984. Public and Private Faces. Kazan, Russia.

DEVLET, N.1991. Islamic revival in the Volga-Ural region. Cahiers du Monde russe et soviétique. Moscow, Russia.

EVDOKIMOV, Valeriy Ivanovich. 1967. "Atheistic education of workers in the process of building communism" In: Questions of scientific atheism. Vol. 4, pp. 94-129.

FAZLIEV, Aivaz; IBRAGIMOV, Ruslan; GALEEVA, Mariam; SATTAROVA, Adelya. 2018. "The national-religious discourse and the political system of modern Russia” In: Dilemas contemporaneos-educacion politica y valores. Vol. 6, p. 81.

FILIMONOV, Elina. 1983. Islam in the USSR: Features of the process of secularization in the republics of the Soviet East. Mysl. Kazan, Russia.

FLETCHER, William. 1973. Religion and Soviet Foreign Policy, 1945-1970. Oxford University Press. London, UK.

ISHMUKHAMETOV, Zoli. 1979. The social role and evolution of Islam in Tatarstan: (Historical essays). Tatknigoizdat. Kazan, Russia.

IVANOV, Alexei. 2000. Book of Memory of the Victims of Political Repression. Part 1. Tatknigoizdat. Kazan, Russia.

KASYMOV, Gilver. 1932. Essays on the religious and anti-religious movement of the Tatars before and after the revolution. M. Kazan, Russia

KORNILOV, Ivan Petrovich. 2003. Protestantism in Tatarstan: the main stages and features of development (XVIII century - 80-ies of XX century). Abstract of theses for the degree of candidate of historical sciences. Kazan, Russia.

KRASIKOV, Anatolij Andreevič. 2000. State atheism. Religious factor in European and Russian politics. Collection of papers M. Samara, Russia.

KRYLOV, Ivan Andreevich. 1960. "From the history of the propaganda of atheism in the USSR (1923-1925)" In: Questions of the history of religion and atheism. Vol. 8, pp. 166-192.

LEGISLATION ON RELIGIOUS CULTS. COLLECTION OF MATERIALS AND DOCUMENTS. 1971. Public and Private Faces. Kazan, Russia.

LITVIN, Arkadi. 1993. The ban on life: Stalinist repression in Tatarstan. Tatknigoizdat. Kazan, Russia. 
MUKHAMETSHIN, Rustem. 2003. Tatars and Islam in the XX century (Islam in the social and political life of the Tatars and Tatarstan). Fen Publishing House. Kazan, Russia.

NABIEV, Rinat. 1997. Religious associations of the Republic of Tatarstan: Reference book. Kazan University Press. Kazan, Russia.

NABIEV, Rinat. 2002. Islam and the state: the cultural and historical evolution of the Muslim religion in the European East. Kazan University Press. Kazan, Russia.

NADYROV, Georgy. 2000. Mosques of Tatarstan. Publishing House RUIC. Kazan, Russia.

NAFIKOV, Ilsur; NABIEV, Rinat. 2018. "Development of State-Confessional Relations of Tatarstan in Conditions of the Islamic-Orthodox Majority" In: Revista Publicando, Vol. 5, No. 16, pp. 717-724.

National Archives of the Republic of Tatarstan. Fund R-873. Inventory 2. Case 5 .

National Archives of the Republic of Tatarstan. Fund R-873. Inventory 2. Case 19.

National Archives of the Republic of Tatarstan. Fund R-873. Inventory 2. Case 16.

National Archives of the Republic of Tatarstan. Fund R-873. Inventory 2. Case 9.

National Archives of the Republic of Tatarstan. Fund R-873. Inventory 2. Case 28.

National Archives of the Republic of Tatarstan. Fund R-873. Inventory 2. Case 30.

National Archives of the Republic of Tatarstan. Fund R-873. Inventory 2. Case 1.

National Archives of the Republic of Tatarstan. Fund R-873. Inventory 2. Case 1

ODINTSOV, Mikhail. 1990. "Going through the throes" In: Science and religion. Vol. 7, pp. 56-57.

ODINTSOV, Mikhail. 1994. State and Church in Russia: XX century. Luch. Moscow, Russia. 
Ruslan Rustamovich Ibragimov, Aivaz Minnegosmanovich Fazliev y Chulpan Khamitovna Samatova

46 Religious Associations in Tatar Assr under Conditions of Mass Political Repressions of the 1930

ODINTSOV, Mikhail. 1995. "Religious organizations in the USSR: on the eve of and in the first years of World War II (1938-1943)" In: Domestic archives. Vol. 2, pp. 37-67.

POSPELOVSKY, Dmitry. 1995. Russian Orthodox Church in the XX century. Republic. Moscow, Russia.

RORLICH, Azade-Ayse. 1986. The Volga Tatars: A Profile in National Resilience. Hoover Institute Press. Stanford, United States.

YAKUNIN, Valdemir. 2002. Russian Orthodox Church during the Great Patriotic War of 1941-1945: historiography and source study of the problem. Republic. Samara, Russia.

YUNUSOVA, Aislu. 1999. Islam in Bashkortostan. Ufa Printing House. Ufa, Russia.

ZEMSKOV, Viktor. 1995. "To the question of the extent of repression in the USSR” In: Sociological studies. Vol. 9, p. 59. 
Vol.38 NEspecial

Esta revista fue editada en formato digital y publicada en diciembre de 2020, por el Fondo Editorial Serbiluz, Universidad del Zulia. Maracaibo-Venezuela 